\title{
Humanized Interior Design and Teaching Reform under the Background of Aging Society
}

\author{
Lingyu Li \\ Fuzhou University of International Studies and Trade \\ Fuzhou, China
}

\begin{abstract}
With the increase of the aging population, China has entered the aging society, and it is of great importance to care for and pay attention to the humanized design of the interior space of the elderly. The paper aimed to explore the context of humanized interior design under the aging society, and then apply to courseware design to reform teaching method. The method used in this paper was literature review. It reviewed the relevant articles to the interior design and a series of related disciplines theory from the humanized, physical, and psychological and lifestyle aspects. Based on this, some suggestions on the humanized interior design are put forward, and some solutions to the existing problems in indoor living space for the elderly are found. At the same time, it also extends to the issue of teaching reform of courseware design for application-oriented colleges and puts forward countermeasures.
\end{abstract}

Keywords —aging society; interior design; humanized design; courseware design

\section{INTRODUCTION}

On October 18, 2017, Comrade Xi Jinping pointed out in his report to the 19th Congress that implementing the strategy for a healthy China, actively responding to the aging of the population, building a policy system for the elderly, filial piety, respecting the elderly and the social environment, advancing the combination of medical treatment and employment, and accelerating the development cause of Aging Industry. Combing the domestic and foreign scholars on the elderly population in the context of an aging society, and overview of research to explore the existing problems, to realize the elderly psychology, behavioral the elderly, accessibility design, ergonomics and a series of related disciplines and laws and regulations. Also put forward some practical solutions to improve living space, but still have few elderly homes, humanization design, and environmental design of interior space in this area.

With the increasing of aging population, the design of interior living space for elderly people exists many problems, such as old buildings, facilities, equipment simple, narrow bedroom environment, space layout is not reasonable, so that the interior design of elderly people has become a new issue. How to take humanity as the starting point, how to design the environment for the indoor living space for the elderly, to create a good indoor environment without obstacles, to meet the physiological, psychological and social needs of the elderly and to reform the interior curriculum in the university education has become a new topic in interior design.

\section{AGING AND INTERIOR DESIGN ENVIRONMENT}

The characteristics of aging behavioral is that the aging Population refers to the total population due to the reduction in the number of young people, the increase in the elderly population led to the corresponding increase in the proportion of the elderly population dynamics. Internationally, the proportion of people over the age of 60 in the total population reaches $10 \%$ or the proportion of those over 65 in the total population reaches $7 \%$ as the standard for entering a country or an aging society. China's elderly population is larger and the aging rate has accelerated. In 2012, the total population in Mainland China reached $1,355.44$ million. The number of elderly people aged 65 and over was 127.14 million, accounting for $9.4 \%$ of the total population of that year, all exceeding the internationally accepted threshold of $10 \%$ and $7 \%$ of population aging. It highlights the aging of the population structure, which has become an unavoidable important issue.

In recent years, the concept of aging has drawn increasing attention from the international community. The current stage of our country also calls the issue of aging the issue of increasing the influence of older persons on social and economic development, which is to recognize the issue of aging from the perspective of the economic development of humankind. With the emergence of the phenomenon of "aging society", it is required that we, as interior designers, must quickly understand social phenomena, adapt to social development and adopt people-oriented design.

Aging interior environment design: According to the different requirements of the elderly on the living environment and the spatial scale design, the physiological characteristics of the elderly are look forward to a comfortable and safe environment. There are many factors that affect the interior design of the elderly. For example, the difference in the spatial size of the elderly depends on the activities, environmental needs and physical characteristics of the elderly, and this difference is an important basis. The elderly have certain regularity in their daily habits, activities carried out around the family. Elderly people carry out various activities based on housing and reflect the impact of housing on them. Therefore, the design of the indoor environment and residential buildings has an important 
impact. Due to the physiological factors of the elderly, there are limits to their activities. Aging interior environment design means that individualized activities will be designed for individual differences among the elderly. As a result, the elderly may engage in personal activities in such spaces without space restrictions, the elderly can feel comfortable and happy, but also to have a quality of life in the elderly.

\section{HUMANIZED AND INTERIOR DESIGN}

Humanized design refers to the design process, based on the behavior of people, the body's physiological structure, the psychological situation of people, people's thinking, etc., based on the original design of the basic functions and performance of the building and exhibits optimized, so that the residents is very convenient and comfortable to stay. It is the respect and satisfaction to human psychological, physical needs and spiritual pursuit, also is the design of human care and human nature.

The quality of living space design determines the quality of life of people, especially into the aging society, the number of elderly population continues to rise, requiring the community pay attention to the elderly living environment and living space design issues. For the elderly, psychologically and physically have a certain particularity, the design of living space for the elderly not only need to ensure the use of basic functions, but also to meet the characteristics of the elderly to use, should follow the professional design principles, and create a good accessible living environment.

\section{TEACHING REFORM OF INTERIOR DESIGN COURSEWARE}

Courseware is a teaching system, the basic function of courseware is to enable students to achieve effective learning, well-designed courseware, can stimulate student interest in learning, in the shortest possible time to obtain the best learning results. Practice teaching method is used in the interior design class. The teaching activities design are students employed oriented, and students development ability for the purpose, so that students take the initiative to participate in teaching, develop students' subjectivity, autonomy, mobilize students to learn enthusiasm, initiative and creativity, to better optimize the effectiveness of classroom teaching, to adapt to the requirements of the job market. After learning the basic design concepts and basic techniques, students should be given humanized design which is suitable for the aging population. Tithe characteristics of elderly people and humanized knowledge should be applied to the design and production processes, and the theory should be changed into practice. The virtuous cycle of learning PDCA steps are described as follows:

Plan provided by the teacher to create a model rendering, students discuss and finalize the design model. Under the guidance of teachers, students design different styles according to the aging population and humanity, open up students' imagination and creativity, and provide students with a vast and free space to cultivate their ability to learn and develop sustainably ability. Check is a self-assessment by students consciously practice, peer assessment, teachers and students discuss and find out the reasons for the differences in evaluation results. Action reflects the skills of students to enable students to gain experience, enhance the operational ability and the application of the results.

Courseware design must follow the syllabus to solve the theoretical and practical problems in teaching. The teaching goal is refined into "knowledge goal", "skill goal", and "emotional goal". For example, the "creative architectural space" teaching in decorative program design curriculum, use of simulated studio design work scenes and multimedia presentations during teaching process to introduce examples of space creative design, makes abstract analysis into an intuitive experience. Teachers use the blackboard to explain, students sub-group discussions to communicate ideas each other on the "space creativity" class. Then the group use PPT presentation, students ask questions and answers, teachers make summary, and those classroom teaching methods with teacher-students interaction can be used.

\section{EXISTING PROBLEMS AND COUNTERMEASURES}

Humanized design is to continuously adapt to people's material and spiritual needs as the basis for indoor design and development goals, and strive to achieve the harmony between man and nature, and consumer evaluation and satisfaction as a yardstick to assess the success of the design. Humanized design points of the living space suitable for $t$ of an aging population and the problems and countermeasures in the teaching reform are described in "Table I" and "Table II".

TABLE I. HuMANIZED INTERIOR DESIGN POINTS WHICH IS SUITABLE FOR THE AGING POPULATION

\begin{tabular}{|l|l|l|}
\hline Humane principles & \multicolumn{1}{|c|}{ Problems } & \multicolumn{1}{|c|}{ Recommended humanized living space design } \\
\hline Visual comfort & $\begin{array}{l}\text { Physiological function, and visual } \\
\text { deterioration }\end{array}$ & $\begin{array}{l}\text { Color design to create a visual comfort level. Starting from the subjective attitude of } \\
\text { people, integrating the characteristics of human nature to formulate a complete set of } \\
\text { design strategies and programs. }\end{array}$ \\
\hline Physiological needs & Afraid loud noise or sound volume & $\begin{array}{l}\text { Sound design to meet the basic needs of user's behavior, but also allow users to fully } \\
\text { experience the comfort and convenience of the design. }\end{array}$ \\
\hline Physical comfort & Action and reaction will be more sluggish & $\begin{array}{l}\text { Decorative design should pay attention to meet the user's physical needs, to make the } \\
\text { design to achieve the best results. }\end{array}$ \\
\hline Storage design & Memory will be gradually reduced & $\begin{array}{l}\text { The storage rooms should be designed according to the contents of the storage } \\
\text { materials. The principles of classification should also be followed to classify different } \\
\text { objects and to be able to meet the needs of the elderly. }\end{array}$ \\
\hline Accessible Design & Loss of self-care ability & $\begin{array}{l}\text { The accessibility design of the living space for the elderly needs comprehensive } \\
\text { consideration of the entire living space. When the elderly lose their ability to take care } \\
\text { of themselves, some living space must be provided for elder's unobstructed activities. }\end{array}$ \\
\hline
\end{tabular}




\begin{tabular}{|l|l|l|}
\hline Humane principles & \multicolumn{1}{|c|}{ Problems } & \multicolumn{1}{|c|}{ Recommended humanized living space design } \\
\hline $\begin{array}{l}\text { Highlight } \\
\text { personality }\end{array}$ & $\begin{array}{l}\text { The user's personality differences and } \\
\text { special needs }\end{array}$ & $\begin{array}{l}\text { Humanized and personalized interior design is the perfect combination of consumer, } \\
\text { interior space and designer. }\end{array}$ \\
\hline Unified system & $\begin{array}{l}\text { A single emphasis on comfort, } \\
\text { landscaping and other appearance } \\
\text { problems }\end{array}$ & $\begin{array}{l}\text { Humanistic interior design should be a comprehensive, multi-dimensional and unified } \\
\text { systematic design process. }\end{array}$ \\
\hline
\end{tabular}

TABLE II. TEACHING REFORM COUNTERMEASURES OF INTERIOR DESIGN COURSE

\begin{tabular}{|c|c|c|}
\hline Humanized principle & Problems & Teaching reform countermeasures \\
\hline $\begin{array}{l}\text { Catch up with the pace of } \\
\text { the times }\end{array}$ & $\begin{array}{l}\text { Interior design teaching } \\
\text { materials are out of touch } \\
\text { with the times }\end{array}$ & $\begin{array}{l}\text { Let students to watch some recently image data and pictures of interior } \\
\text { design model room, and then ask students to classify and analyze the } \\
\text { different design in order to summarize different design concepts. }\end{array}$ \\
\hline Aging elements & $\begin{array}{l}\text { Interior design courses do not } \\
\text { meet the human design of the } \\
\text { elderly }\end{array}$ & $\begin{array}{l}\text { Let students intuitively understand the course content, aging characteristics } \\
\text { and environmental conditions, how to use the actual project. }\end{array}$ \\
\hline Case Picture & $\begin{array}{l}\text { Concept and content } \\
\text { teaching of Ergonomic are } \\
\text { boring and profound. }\end{array}$ & $\begin{array}{l}\text { Teaching materials must be able to practice operation, the case pictures will } \\
\text { be easy for students to understand and generate interest }\end{array}$ \\
\hline $\begin{array}{l}\text { Theory is too high } \\
\text { proportion of theory } \\
\text { teaching }\end{array}$ & $\begin{array}{l}\text { Ergonomic theory taught } \\
\text { accounted for } 80 \% \text {, where } \\
\text { practice class } 20 \% \text { only. }\end{array}$ & $\begin{array}{l}\text { Applied undergraduate college universities mainly cultivate students' } \\
\text { practical operation, theory teaching accounted for } 40 \% \text {, and practice class } \\
60 \% \text { at least. }\end{array}$ \\
\hline
\end{tabular}

\section{CONCLUSION}

Applied teaching reform focus on practice, in order to promote students to do in line with the social requirements of current society and industrial needs. Interior design courses are no exception. At present, China's access to an aging society, interior design textbooks should consider the elderly and humanity, but also to understand the elderly with age, the physical and mental will have some changes, more likely to have negative psychological emotions. In response to this situation, optimizing the living space for the elderly to meet the different needs of the elderly plays an important role. Elderly physical characteristics are unique; to maintain a comfortable mood can ease the lonely feelings of the elderly, comfortable living environment can improve the quality of life of the elderly, and promote the formation of a harmonious society.

\section{REFERENCES}

[1] Zhang Zhiling. Analysis of residential space design of elderly people [J]. Residential technology, 2009 (02).

[2] Chengkun. A preliminary study on the design of residential space for the elderly [D]. Tianjin University, 2013.

[3] Zhou Lin, hang kikuyu. The design of residential space for the elderly [J]. Shanxi architecture, 2005 (24).

[4] Liu Yang. Research on the design requirements of residential space in the elderly [J]. Science and technology economy market, 2014 (10).

[5] Lin Yinda. Reflections on aging society interior design [J]. Journal of Fujian engineering college, 2011(3). 